\title{
Ecology and consequences of invasion by non-native (wilding) conifers in New Zealand
}

\author{
Manaaki Whenua Landcare Research, 54 Gerald St., Lincoln 7608, New Zealand \\ D.A. PELTZER
608, New Zealand
areresearch.co.nz
}

\begin{abstract}
Invasion by non-native woody species into largely treeless vegetation such as grasslands and shrublands is widespread, and has prompted both research and management in response. Here I review the current situation of invasions by non-native Pinaceae, better known as 'wilding conifers' in New Zealand, and how both research and management are working to better understand and manage these invaders. The success of wildings is explained by a combination of history (e.g., deforestation of previously woody vegetation), biological traits of the species (rapid growth and early reproduction), and propagule pressure (introduction effort). Wildings represent a major land use change affecting about 2 million ha, including many grasslands, rare ecosystems and subalpine habitats. Wilding invasions into grasslands have profound impacts on biological diversity, but also have important ecosystem impacts including legacy effects belowground by altering nutrient cycling and soil biota. Recent expanded efforts are underway to control and co-ordinate management to avoid or mitigate the negative impacts of wilding conifers. The long-term value of managing invasions, and whether additional management interventions are needed to restore grasslands or woody vegetation is in progress, but is urgently needed given recent moves to widely establish new woody vegetation at large scales in New Zealand.
\end{abstract}

Keywords: biological invasions, ecological impacts, ecosystem legacies, non-native tree species, Pinus contorta, plant-soil interactions, removal effects, wilding conifers

\section{Introduction}

Biological invasions by non-native species are an important component of global change, and are a major driver of changes in ecological communities and ecosystems (Vitousek et al. 1997; Early et al. 2017). Moreover, many of these drivers interact, for example, changing land use or climate can exacerbate the number or success of biological invaders in a system (Tylianakis et al. 2008). More specifically, New Zealand is one of the world's most invaded countries. This is highlighted through such national-scale efforts as predator-free New Zealand. For plants, about half of the New Zealand flora is comprised of non-native plant species, and many of these are considered environmental weeds. As a consequence, there are ongoing efforts to better understand and manage biological invasions at both regional and national scales.

Invasion by non-native tree species into non-forested areas is a global problem because tree invasions can drive declines in conservation values or biodiversity as well as altering land use suitability for agriculture or other primary industries (Richardson \& Rejmánek 2011). Internationally, one of the best studied and most widespread group of invasive non-native trees are the pines (Pinaceae); this is unsurprising given their widespread deliberate introduction for timber, fibre and shelter (Richardson \& Rejmánek 2004; Procheş et al. 2011). Invasive Pinaceae have become widely naturalised in the southern hemisphere (Richardson et al. 1994; Simberloff et al. 2010). Most literature refers to these species as invasive non-native Pinaceae or conifers; but the more succinct New Zealand term is "wilding conifers" (Froude 2011). Wildings represent about a dozen species including lodgepole and back pine (Pinus contorta, P. nigra), Douglas fir (Pseudotsuga menziesii) and larch (Larix decidua) (McGregor et al. 2012). Below, I briefly review why these species are so successful, why they are a problem, what is currently being done to manage wildings, and finish with some longer term or unresolved issues.

\section{So why are wildings so successful?}

Successful establishment, naturalisation and spread of introduced species is often attributed to their biological characteristics such as rapid growth, high reproductive output and tolerance of environmental conditions. For example, lodgepole pine (Pinus contorta) grows much faster in countries where it has been introduced compared to the home range in North America (Ledgard 2001; Taylor et al. 2016a). However, for pine species introduced to New Zealand the best predictors of naturalisation are introduction effort (forestry use, area planted, and date of introduction) and climatematching; the main biological trait is early age to reproduction (McGregor et al. 2012). In addition, seed traits (terminal velocity, or the rate of seed fall vertically) and wind, interact to drive both short and long-distance dispersal of conifers, and in combination with high survivorship of seedlings, this allows pine invasions to rapidly establish in grasslands (Buckley et 
al. 2005; Caplat et al. 2012). Overall, this demonstrates that early, large-scale plantings overcome the lag times between when a species is introduced and when it becomes naturalised and invasive, but also suggests that some species that are not currently widespread invaders are able to spread, but are just taking longer to invade because of lower initial introduction effort.

Positive interactions can also occur among introduced species. For conifers, the most obvious is mutualisms involving mycorrhizas: beneficial fungi associated with plant roots that are needed for tree establishment and can improve the subsequent survival and growth of plants. For example, lodgepole pine co-invades with non-native mycorrhizal fungi rather than associating with native fungi (Dickie et al. 2010), and even a single mycorrhizal species can enable pine invasion (Hayward et al. 2015). Furthermore, few mycorrhizal fungal species are needed to facilitate pine invasion, including into grasslands that do not contain ectomycorrhizal tree species. This differs from native beech (nothofagus) tree species that are also ectomycorrhizal, but are notoriously slow at reinvading grasslands. In addition, non-native mycorrhizal fungi can be transported by non-native mammals such as deer and possums, but presumably other mammals can also disperse fungi (Wood et al. 2015). Positive interactions amongst wilding tree species, their coinvading mycorrhizal fungi and dispersal of these fungi by non-native mammals helps to explain the invasion success of wilding conifers into grasslands (Figure 1).

\section{Why are wildlings a problem?}

The invasion by trees into grassland has both obvious consequences and less obvious legacies. Although the invasion potential of conifers has been known for some time (e.g., Benecke 1967; Hunter \& Douglas 1984; and references in Froude 2011), wildings are now broadly viewed as a serious threat to grassland biodiversity, pasture or primary production, and some ecosystem processes, through profoundly altering vegetation composition and resource availability (Dickie et al. 2011; Rundel et al. 2014; Taylor et al. 2016b). Different impacts of wildings occur at different stages of the invasion process. Grassland plant diversity can initially increase with invasion but then rapidly declines; carbon scales positively and linearly with increasing tree density; and water yield declines most rapidly with canopy closure because of rainfall interception (Fahey $\&$ Payne 2017). As a consequence, different impacts of wildings occur as invasion proceeds, and this can create trade-offs in net impacts, or conversely, the benefits of managing invasions for conservation or primary production (Mason et al. 2017). The less obvious legacies of wildings include belowground changes to nutrient cycling and the soil biota that can persist
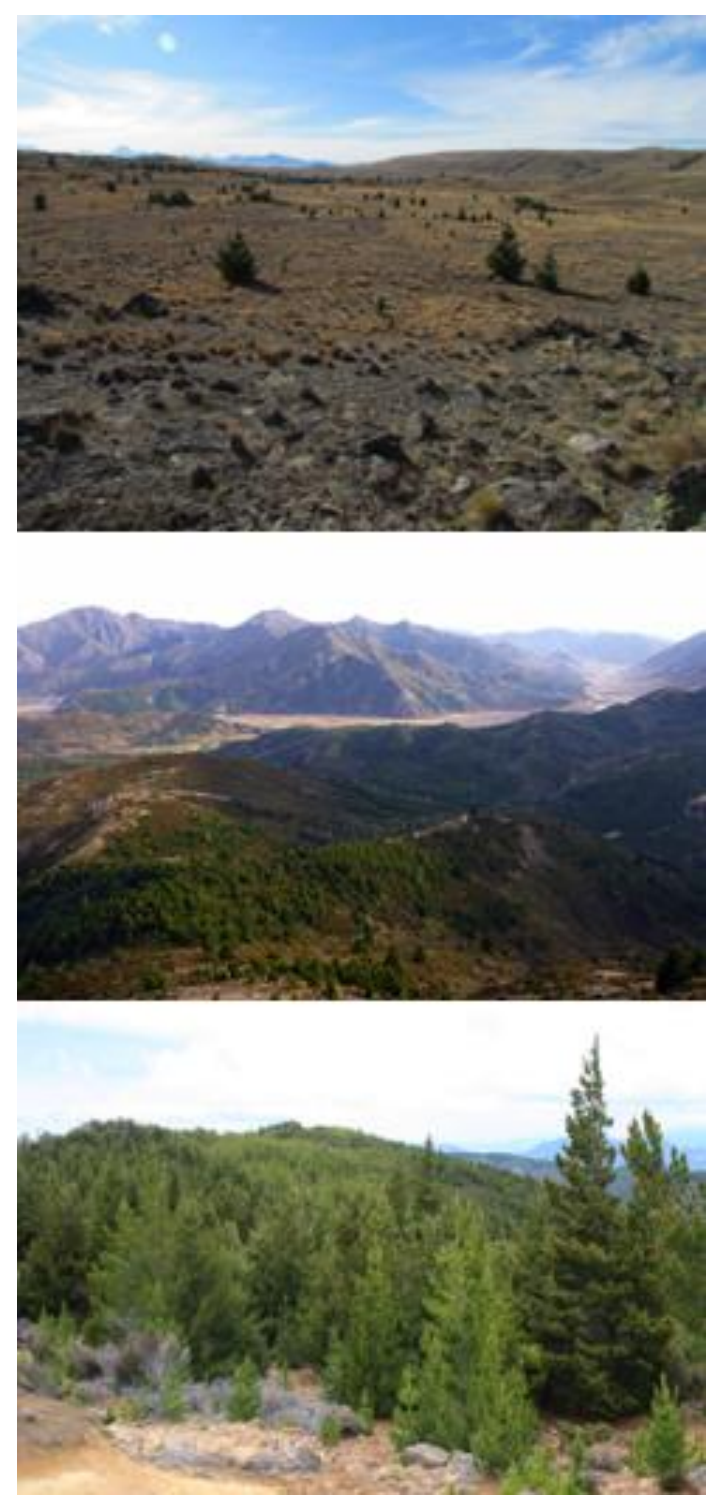

Figure 1

Invasion by non-native pines or 'wilding conifers'. Early invasion in the Mackenzie Basin (top panel), ongoing invasion near Hanmer Springs (middle panel), and a long-invaded site in the Kawekas (bottom panel).

following the control of wildings (Dickie et al. 2014). This includes increases in both soil available nitrogen and phosphorus compared to native grasslands, and changes in plant-associated nematodes that can act as pathogens. What is surprising is how rapidly impacts and legacies can develop ( $<10$ years) given the invasion is by tree species (Figure 1; Taylor et al. 2016a).

The total area affected by wildings (defined as a minimum of one tree/ha) is thought to be around 2 million ha, or about the same area as is in plantation 
forestry in New Zealand (MPI 2014). The area invaded has by some estimates increased by about 5\%/year over the past few decades. Because wildings can invade high-country grasslands, threaten rare ecosystems (many of which are treeless vegetation and have high conservation value), and can establish above the natural treeline, they are considered a national-scale weed issue (Froude 2011). The speed and scale of wilding invasion occurred despite ongoing management efforts by landowners, community trusts and government departments alike, and this prompted a call for increased management to contain or eradicate wildings. In response, the Ministry of Primary Industry spearheaded a national strategy to raise general awareness of this issue, and to co-ordinate management efforts amongst central and regional government, landowners and industry at a national scale (MPI 2014). More recently, this has prompted formation of the National Wilding Conifer Management Programme that organises and co-ordinates these renewed management efforts (www. wildingconifers.org.nz).

\section{What is currently being done to manage wildings?}

In response to widespread invasion, there are many management programs internationally that are pursued to prevent or mitigate the spread and impacts of biological invaders (e.g., Hulme 2015; Nuñez et al. 2017). Usually, multiple management strategies are deployed in an attempt to reduce the abundance or distribution of invasive species, but with an ultimate goal of avoiding or mitigating negative impacts on native ecosystems (e.g., Zavaleta et al. 2001; Barney et al. 2015). For wilding conifers there are multiple methods used for controlling trees that are used depending on tree density, the species involved and site access. These include mechanical (grubbing, pulling, cutting, mulching) and chemical (ground and aerial basal bark herbicides, aerial boom spraying) methods as well as land management (mob stocking, pasture improvement). The selection and use of different management strategies is well-covered in work plans, user guides and vast previous experience (e.g., Ledgard 2009; Briden et al. 2014; Gous et al. 2014, 2015). Current total spending nationally wilding control is about $\$ 16$ million/year, but this excludes ongoing management efforts on private land and by communities (MPI 2014).

Selection of different management strategies typically considers the effectiveness of control (e.g., proportion of trees killed) and cost, and in some cases, the response of native communities (Flory \& Clay 2009). A few studies that consider the non-target impacts of wildings show that changes in plant communities caused by both wilding invasion and different management or removal

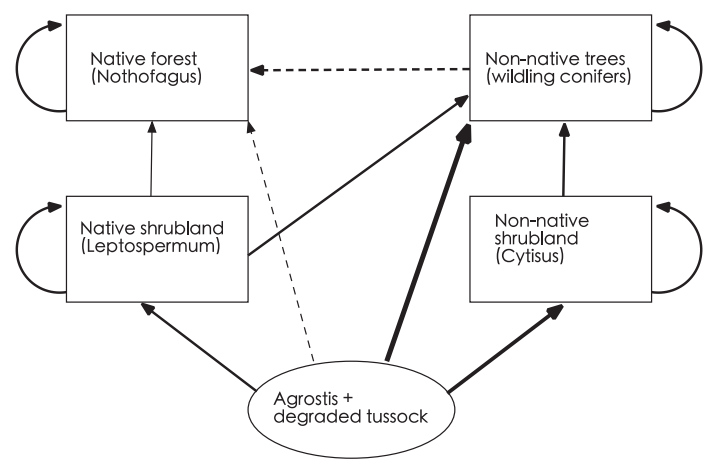

Figure 2 Illustrative state and transition model for grasslands modified and simplified from Standish et al. (2009). Arrows show vegetation changes from tussock grassland towards dominance by either native (left side) or non-native weeds (right side). Depending on propagule pressure (seed sources) and environment, most trajectories tend towards dominance by non-native trees or wilding conifers, but in some cases states can persist through self-replacement (shown by loops for a vegetation-type).

strategies have contrasting outcomes for vegetation recovery. For example, early control of wilding seedling or saplings returned a tussock grassland community to resemble the uninvaded community, whereas later removal of trees drove the vegetation towards dominance by few non-native grasses (e.g., Agrostis capillaris, Anthoxanthum odoratum; Ledgard \& Paul 2008; Paul \& Ledgard 2009; Dickie et al. 2014). Overall, woody invasion into grasslands follows somewhat predictable state and transitions (Figure 2), but the rapid shift towards dominance of wilding conifers rather than native woody plant species is a major concern (Standish et al. 2009; Young et al. 2016). More specifically, management of wildings can have different outcomes depending on the methods used and the more rapid establishment of many non-native plants compared to native species (Wardle \& Peltzer 2017). Other potential management tools including fire, biological control and the use of sterile trees in plantations, are all options for efficient longer-term management to prevent future wilding spread, but are not currently in use.

Many invasive plant management or eradication efforts in general either fail to meet their stated management goals or do not carry out rigorous evaluations of success (e.g., Maxwell et al. 2009; Wilson et al. 2014); those that do measure effectiveness as change in invasive species to management per se rather than wider values or benefits (Reid et al. 2009). However, an implicit goal of management, including of wildings, is often to generate benefits beyond immediate control of the invader itself. These benefits 


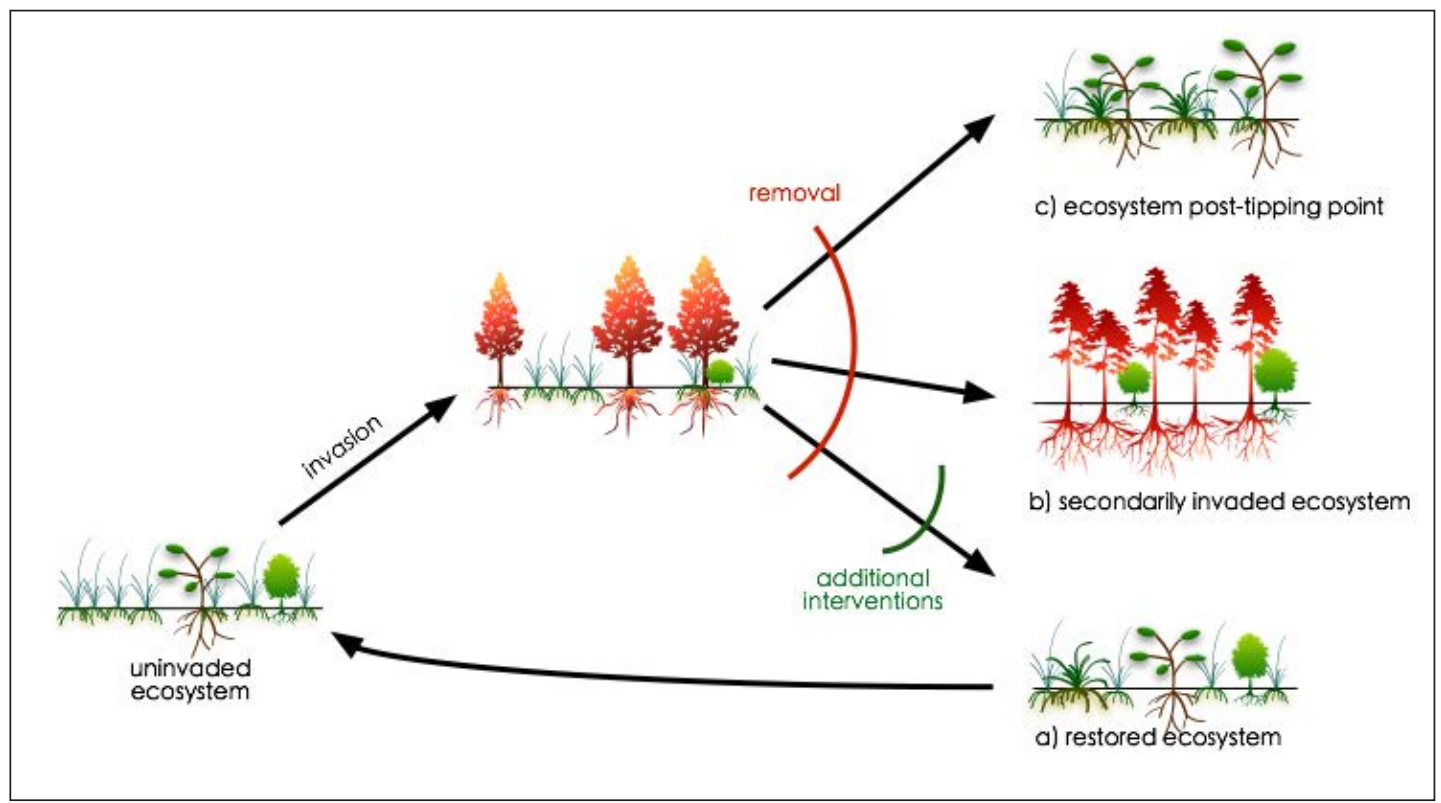

Figure 3 General trajectories of changes driven by invasion, invader removal or restoration. Management ('removal') of invaders can involve creating a new system (top right), reinvasion by wildings or secondary invasion by other weeds (middle right), or with sufficient seed sources or additional management, restoration towards an uninvaded system (bottom left) (modified from Wardle \& Peltzer 2017).

span conservation of sites and native species, sustained water yield in catchments, and maintaining landscape values (MPI 2014; Nuñez et al. 2017).

\section{Looking ahead}

Non-native conifers in New Zealand are an interesting issue globally because they both underpin the plantation forest industry, but at the same time most species are also considered environmental weeds. The two issues are not directly comparable, however, because both the tree species involved and locations can differ between plantation forestry and wilding invasion. Overall, wildings are currently a widespread weed problem of non-native trees invading largely into grasslands and other non-forest vegetation-types, but new progress in management to contain or eradicate wildings is now being made through greater co-ordination and operational funding at a national scale (http://wildingconifers.org.nz/ about-us/programme-2/). However, there remain several opportunities or gaps in understanding that remain to be filled, and that closely linking management and research can help to resolve including:

1. There is no one-off management method that can eliminate wildings in perpetuity, but rather followup or repeated management is typically needed (Ledgard 2009; Nuñez et al. 2017). Determining how long management must endure to control or contain wildlings is needed, but planning for a decade or longer is often essential.
2. If eradication or elimination of wilding conifers is not possible for a site, then what is the minimal wilding abundance that management should achieve to ensure benefits within a site (Barney et al. 2015)? In other words, can sustaining a low abundance of wildings provide nearly all of the benefits of management?

3. Taking a longer-term view, are additional management interventions needed to establish grassland or native woody species (e.g., McAlpine et al. 2016), or to prevent undesirable 'secondary invasions' by other non-native species (Figure 3; see also Firn et al. 2010)? The long-term options for wilding invaded sites converge on active management towards grassland (either native tussock or pasture), or woody vegetation (most likely mixtures of native and nonnative woody species); making the end-point explicit is necessary to know when and what additional management efforts are needed.

4. What is the future risk of wilding invasion given changes in land use, climate and management? This is particularly pressing given that ongoing, largescale changes in land use are likely (e.g., driven by the billion trees Government initiative), and the prediction that future climates might alter both plant performance (growth, height and reproductive effort) and extreme events (e.g., storms), thus potentially increasing spread risk (Caplat et al. 2013).

Controlling invasive non-native species such as wilding conifers is at the same time both simple (i.e., killing 
unwanted trees) and complex because it involves manipulation of complex systems across all stages of the invasion process from preventing new invasions, to managing established populations, and in a few cases, sorting out long-invaded areas. Because the outcomes of invasive species removal, in terms of conservation values and ecosystem impacts, are often variable (Kettenring \& Adams 2011), it is essential to evaluate the performance of different management strategies. The renewed efforts and co-ordination of wilding management and research give new hope that effective control of wilding conifers will prevent or mitigate their negative effects at the landscape-scale.

\section{ACKNOWLEDGEMENTS}

I thank the numerous colleagues and collaborators who have helped to develop these ideas, brought into particular focus recently through the National Wilding Conifer Control Programme for wilding conifer management, and the Winning Against Wildings research programme funded by the New Zealand Ministry of Business, Innovation and Employment.

\section{REFERENCES}

Barney, J.N.; Tekiela, D.R.; Barrios-Garcia, M.N.; Dimarco, R.D.; Hufbauer, R.A.; Leipzig-Scott, P.; Nunez, M.A.; Pauchard, A.; Pyšek, P.; Vítková, M.; Maxwell, B.D. 2015. Global Invader Impact Network (GIIN): toward standardized evaluation of the ecological impacts of invasive plants. Ecology and Evolution 5: 2878-2889.

Benecke, U. 1967. The weed potential of lodgepole pine. Tussock Grasslands and Mountain Lands Institute Review 13: 36-42.

Briden, K.; Raal, P.; Gous, S. 2014. Improving methods for wilding conifer control in New Zealand. pp. 369-371. In: Proceedings of 19th Australian weeds conference, Hobart, Tasmania, Australia.

Buckley, Y.M.; Brockerhoff, E.; Langer, L.; Ledgard, N.; North, H.; Rees, M. 2005. Slowing down a pine invasion despite uncertainty in demography and dispersal. Journal of Applied Ecology 42: 1020-1030.

Caplat, P.; Nathan, R.; Buckley, Y.M. 2012. Seed terminal velocity, wind turbulence, and demography drive the spread of an invasive tree in an analytical model. Ecology 93: 368-377.

Caplat, P.; Cheptou, P.O.; Diez, J.; Guisan, A.; Larson, B.M.; MacDougall, A.S.; Peltzer, D.A.; Richardson, D.M.; Shea, K.; van Kleunen, M.; Zhang, R. 2013. Movement, impacts and management of plant distributions in response to climate change: insights from invasions. Oikos 122: 1265-1274.

Dickie, I.A.; Bolstridge, N.; Cooper, J.A.; Peltzer, D.A. 2010. Co-invasion by Pinus and its mycorrhizal fungi. New Phytologist 187: 475-484.
Dickie, I.A.; Yeates, G.W.; John, M.G.S.; Stevenson, B.A.; Scott, J.T., Rillig, M.C.; Peltzer, D.A.; Orwin, K.H.; Kirschbaum, M.U.; Hunt, J.E.; Burrows, L.E. 2011. Ecosystem service and biodiversity tradeoffs in two woody successions. Journal of Applied Ecology 48: 926-934.

Dickie, I.A.; St John, M.G.; Yeates, G.W.; Morse, C.W.; Bonner, K.I.; Orwin, K.; Peltzer, D.A. 2014. Belowground legacies of Pinus contorta invasion and removal result in multiple mechanisms of invasional meltdown. AoB PLANTS, 6, plu056-plu056.

Early, R.; Bradley, B.A.; Dukes, J.S.; Lawler, J.J.; Olden, J.D.; Blumenthal, D.M.; Gonzalez, P.; Grosholz, E.D.; Ibañez, I.; Miller, L.P. ; Sorte, C.J. 2016. Global threats from invasive alien species in the twenty-first century and national response capacities. Nature Communications 7: 12485. doi: 10.1038/ncomms 12485

Fahey, B.; Payne J. 2017. The Glendhu experimental catchment study, upland east Otago, New Zealand: 34 years of hydrological observations on the afforestation of tussock grasslands. Hydrological Processes 31: 2921-2934.

Flory, S.L.; Clay, K. 2009. Invasive plant removal method determines native plant community responses. Journal of Applied Ecology 46: 434-442.

Firn, J.; House, A.P.N.; Buckley, Y.M. 2010. Alternative states models provide an effective framework for invasive species control and restoration of native communities. Journal of Applied Ecology 47: 96105.

Froude, V.A. 2011. Wilding conifers in New Zealand: status report. Prepared for the Ministry of Agriculture and Forestry. Bay of Islands, New Zealand, Pacific Eco-Logic Ltd.

Gous, S.; Raal, P.; Watt, M.S. 2014. Dense wilding conifer control with aerially applied herbicides in New Zealand. New Zealand Journal of Forestry Science 44: 4.

Gous, S.; Raal, P.; Kimberley, M.O.; Watt, M.S. 2015. Chemical control of isolated invasive conifers using a novel aerial spot application method. Weed Research 55: 380-386.

Hayward, J.; Horton, T.R.; Pauchard, A.; Nuñez, M.A. 2015. A single ectomycorrhizal fungal species can enable a Pinus invasion. Ecology 96: 1438-1444.

Hulme, P.E. 2015. Invasion pathways at a crossroad: policy and research challenges for managing alien species introductions. Journal of Applied Ecology 52: 1418-1424.

Hunter, G.G.; Douglas, M.H. 1984. Spread of exotic conifers on South Island Rangelands. New Zealand Journal of Forestry 29: 78-96.

Kerr, N.Z.; Baxter, P.W.J.; Salguero-Gómez, R.; Wardle, G.M.; Buckley, Y.M. 2016. Prioritizing management 
actions for invasive populations using cost, efficacy, demography and expert opinion for 14 plant species world-wide. Journal of Applied Ecology 53: 305316.

Kettenring, K.M.; Adams, C.R. 2011. Lessons learned from invasive plant control experiments: a systematic review and meta-analysis. Journal of Applied Ecology 48: 970-979.

Ledgard, N.J. 2001. The spread of lodgepole pine (Pinus contorta, Dougl.) in New Zealand. Forest Ecology and Management 141: 43-57.

Ledgard, N.J. 2009. Wilding control. Guidelines for the control of wilding conifers. Scion, Rotorua. ISBN 0-478-11028-6

Ledgard, N.J.; Paul, T.S.H. 2008. Vegetation successions over 30 years of high country grassland invasion by Pinus contorta. New Zealand Plant Protection 61: 98-104.

Mason, N.W.H.; Palmer, D.J.; Vetrova, V.; Brabyn, L.; Paul, T.; Willemse, P.; Peltzer, D.A. 2017. Accentuating the positive while eliminating the negative of alien tree invasions: a multiple ecosystem services approach to prioritising control efforts. Biological Invasions 19: 1181-1195.

Maxwell, B.D.; Lehnhoff, E.; Rew, L.J. 2009. The rationale for monitoring invasive plant populations as a crucial step for management. Invasive Plant Science and Management 2: 1-9.

MPI. 2014. The right tree in the right place: New Zealand wilding conifer management strategy 20152030. A non-regulatory strategy for the management of wilding conifers in New Zealand. Ministry of Primary Industry of New Zealand, 40 pp. ISBN: 9780-477-10511-8

McAlpine, K.G.; Howell, C.J.; Wotton, D.M. 2016. Effects of tree control method, seed addition, and introduced mammal exclusion on seedling establishment in an invasive Pinus contorta forest. New Zealand Journal of Ecology 40: 302-309.

McGregor, K.F.; Watt, M.S.; Hulme, P.E.; Duncan, R.P. 2012. What determines pine naturalization: species traits, climate suitability or forestry use? Diversity and Distributions 18: 1013-1023.

Nuñez, M.A.; Chiuffo, M.C.; Torres, A.; Paul, T.; Dimarco, R.D.; Raal, P.; Policelli, N.; Moyano, J.; García, R.A.; van Wilgen, B.W.; Pauchard, A. 2017. Ecology and management of invasive Pinaceae around the world: progress and challenges. Biological Invasions 19: 3099-3120.

Paul, T.S.H.; Ledgard, N.J. 2009. Vegetation succession associated with wilding conifer removal. New Zealand Plant Protection 62: 374-379.

Procheş, Ş.; Wilson, J.R.U.; Richardson, D.M.; Rejmánek, M. 2012. Native and naturalized range size in Pinus: relative importance of biogeography, introduction effort and species traits. Global Ecology and Biogeography 21: 513-523.

Reid, A.M.; Morin, L.; Downey, P.O.; French, K.; Virtue, J.G. 2009. Does invasive plant management aid the restoration of natural ecosystems? Biological Conservation 142: 2342-2349.

Richardson, D.M.; Rejmánek, M. 2004. Conifers as invasive aliens: a global survey and predictive framework. Diversity and Distributions 10: 321-331.

Richardson, D.M.; Rejmánek, M. 2011. Trees and shrubs as invasive alien species - a global review. Diversity and Distributions 17: 788-809.

Richardson, D.M.; Williams, P.A.; Hobbs, R.J. 1994. Pine invasions in the Southern Hemisphere: determinants of spread and invadability. Journal of Biogeography 21: 511-527.

Rundel, P.W.; Dickie, I.A.; Richardson, D.M. 2014. Tree invasions into treeless areas: Mechanisms and ecosystem processes. Biological Invasions 16: 663675.

Simberloff, D.; Nuñez, M.A.; Ledgard, N.J.; Pauchard, A.; Richardson, D.M.; Sarasola, M.; Van Wilgen, B.W.; Zalba, S.M.; Zenni, R.D.; Bustamante, R.; Peña, E. 2010. Spread and impact of introduced conifers in South America: Lessons from other southern hemisphere regions. Austral Ecology 35: 489-504

Standish, R.J.; Sparrow, A.D.; Williams, P.A.; Hobbs, R.J. 2009. A state-and-transition model for the recovery of abandoned farmland in New Zealand. pp. 189-205. In: New models of ecosystem dynamics and restoration. Eds. Hobbs R.J.; Suding, K.N. Island Press, Washington, DC.

Taylor, K.T.; Maxwell, B.D.; Pauchard, A.; Nuñez, M.A.; Peltzer, D.A.; Terwei, A.; Rew, L.J. 2016a. Drivers of plant invasion vary globally: evidence from pine invasions within six ecoregions. Global Ecology and Biogeography 25: 96-106.

Taylor, K.T.; Maxwell, B.D.; Pauchard, A.; Nuñez, M.A.; Rew, L.J. 2016b. Native versus non-native invasions: similarities and differences in the biodiversity impacts of Pinus contorta in introduced and native ranges. Diversity and Distributions 22: 578-588.

Tylianakis, J.M.; Didham, R.K.; Bascompte, J.; Wardle, D.A. 2008. Global change and species interactions in terrestrial ecosystems. Ecology Letters 11: 13511363.

Vitousek, P.M.; D'antonio, C.M.; Loope, L.L.; Rejmanek, M.; Westbrooks, R. 1997. Introduced species: a significant component of human-caused global change. New Zealand Journal of Ecology 21: 1-16.

Wardle, D.A.; Peltzer, D.A. 2017. Impacts of invasive biota in forest ecosystems in an aboveground- 
belowground context. Biological Invasions 19: 33013316.

Wilson, J.R.; Caplat, P.; Dickie, I.A.; Hui, C.; Maxwell, B.D.; Nuñez,, M.A.; Pauchard, A.; Rejmánek, M.; Richardson, D.M.; Robertson, M.P.; Spear, D. 2014. A standardized set of metrics to assess and monitor tree invasions. Biological Invasions 16: 535-551.

Wood, J.R.; Dickie, I.A.; Moeller, H.V.; Peltzer, D.A.; Bonner, K.I.; Rattray, G.; Wilmshurst, J.M. 2015. Novel interactions between non-native mammals and fungi facilitate establishment of invasive pines. Journal of Ecology 103: 121-129.

Young, L.M.; Norton, D.A.; Lambert, M.T. 2016. One hundred years of vegetation change at Cass, eastern South Island high country. New Zealand Journal of Ecology 40: 289-301.

Zavaleta, E.S.; Hobbs, R.J.; Mooney, H.A. 2001. Viewing invasive species removal in a wholeecosystem context. Trends in Ecology and Evolution 16: 454-459. 
